\title{
Predicting Fraudulent Financial Statement Risk: The Testing Dechow F-Score Financial Sector Company Inindonesia
}

\author{
Nurcahyono Nurcahyono ${ }^{1, *}$, Ayu Noviani Hanum ${ }^{1}$, Ida Kristiana ${ }^{1}$, Imang Dapit Pamungkas ${ }^{2}$ \\ ${ }^{1}$ Department of Accounting, Universitas Muhammadiyah Semarang, Indonesia \\ ${ }^{2}$ Department of Accounting, Universitas Dian Nuswantoro, Indonesia
}

Received September 9, 2021; Revised October 25, 2021; Accepted November 21, 2021

\section{Cite This Paper in the following Citation Styles}

(a): [1] Nurcahyono Nurcahyono, Ayu Noviani Hanum, Ida Kristiana, Imang Dapit Pamungkas, "Predicting Fraudulent Financial Statement Risk: The Testing Dechow F-Score Financial Sector Company Inindonesia," Universal Journal of Accounting and Finance, Vol. 9, No. 6, pp. 1487-1494, 2021. DOI: 10.13189/ujaf.2021.090625.

(b): Nurcahyono Nurcahyono, Ayu Noviani Hanum, Ida Kristiana, Imang Dapit Pamungkas (2021). Predicting Fraudulent Financial Statement Risk: The Testing Dechow F-Score Financial Sector Company Inindonesia. Universal Journal of Accounting and Finance, 9(6), 1487-1494. DOI: 10.13189/ujaf.2021.090625.

Copyright $@ 2021$ by authors, all rights reserved. Authors agree that this article remains permanently open access under the terms of the Creative Commons Attribution License 4.0 International License

\begin{abstract}
This study aims to empirically examine the factors that can be used to detect the risk of Fraudulent financial statements. Fraudulent financial statement is an interesting topic to study, because it has a huge impact on business sustainability and the country's economy may become a crisis. The research population is the financial sector companies listed on the Indonesia Stock Exchange in 2018-2021. The sampling technique uses purposive sampling. The number of companies that meet the sample criteria is 76 companies, so there are 228 observations. Data analysis used Moderated Regression Analysis for hypothesis testing. The results show that companies which provide shares for managers and streamline the role of the whistleblowing system and audit committee will prevent companies from committing fraud, because they act as internal controls. Auditor switching and management arrogance are early indicators that can be used for fraud detection, because the strategy of management is to hide crimes. Financial ratios are certainly the easiest indicator to detect fraudulent financial statements risk, profitability, liquidity, and solvency of a company that is small or minus will encourage management to commit fraud so that the company looks good. Also, organizational culture can reduce the risk of fraudulent financial statements if it is properly internalized.
\end{abstract}

Keywords Fraud, Managerial Ownership, Auditor Switching, Financial Ratios, Organizational Culture

\section{Introduction}

Fraudulent financial statement is a misstatement or intentional omission of amounts or disclosures in financial statements to deceive financial statement users [1]. Fraud will threaten the sustainability of the business [2] and harm the macroeconomy, for example, the case of fraud committed by Enron, WorldCom, Qwest, Tyco, and Global Crossing with a loss of \$ 460 [2,3]. Fraud has become a big enemy of corporations and the state; according to the Association of Certified Fraud Examiners' survey (A.C.F.E.) in 2019, there were 239 cases of fraud with a loss of IDR 873.4 billion, 20.9\% cases of misappropriation of assets with a loss of IDR 257.5 billion; corruption in $69.9 \%$ cases with a loss of IDR 373.6 billion; financial statement fraud in $9.2 \%$ cases with a loss of 242.3 billion [2].

Fraudulent financial statements resulted in substantial losses with few cases, with the financial industry being the most disadvantaged, around $41.4 \%$ of the total loss [2]. Fraud often occurs by manipulating financial statements through account takeovers, loan fraud, account transfers, and checks. According to studies $[4,5,6,7,8]$ the risk of fraud can be reduced by good corporate governance. The 
company has an excellent financial condition, reflected in financial ratios and internalization of organizational culture to control management behavior. Detection of fraud risk in financial statements using the Dechow F-score is considered to have better accuracy than other measurements [9].

The Dechow F-score is better for detecting fraud in developing countries than the Benes M-score [9]. According to [9], developed countries have better fraud control and supervision instruments than developing countries. Of course, set and developing countries have different characters, so the Dechow F-score is suitable for developing countries. This study adds a variable whistleblowing system that is not used $[9,10,11]$. Implementing an effective whistleblowing system is the most effective tool for detecting fraud as a form of the principle of corporate transparency [9,11]. Also, the internalization of organizational culture is the main component of the company to control the increase in financial statement fraud.

\section{Literature Review}

Fraudulent financial reporting is a deliberate act to increase stock prices for personal purposes or deceive financial statement users [1]. Fraud usually occurs when a company heighten assets and revenues or when a company understates liabilities and costs. Financial reports are generally carried out by agents who have the opportunity; based on a survey conducted by A.C.F.E. in 2018, most frauds were committed by directors, managers, and company internal parties [2]. Fraudulent financial statements usually involve falsification, manipulating financial records and business documents, intentionally omitting significant transactions, accounts and information. In addition, the use of accounting principles and disclosure procedures is not appropriate and eliminates information that should be disclosed about the accounting principles and policies used [12,13]. The variables used are Good Corporate Governance (G.C.G.), financial ratios, and organizational culture.

G.C.G. is a company's internal control system that has as its primary goal the management of substantial risks to the company's business objectives, to secure the company's assets and increase the value of the shareholder investment over time [14]. The concept of G.C.G. guarantees the rights of stakeholders to obtain correct and timely information and the company's obligation to make accurate, convenient, and transparent disclosures of all company information on financial statements. The benefits of G.C.G. for companies are that it improves performance and corporate value, and minimizes agency costs $[14,15,16]$. G.C.G.'s mechanism, in the form of managerial ownership, whistleblowing system, C.E.O. arrogance, and audit committee [12,17], explains the effectiveness of the G.C.G. structure in reducing the possibility of financial statement fraud.

Financial reporting fraud can be minimized with management involvement in share ownership. Managerial ownership can avoid the possibility of differences in interests between stakeholders, and management will be more prudent in presenting financial statements and be more motivated to increase the company's value so that management works by the interests of the principal. Weak corporate governance will provide opportunities for managers to commit financial statement fraud. A study by Shi et, al [18] proved that the higher the percentage of Managerial ownership, the lower the probability of financial statement fraud. A study $[17,18]$ revealed that managerial ownership harms financial statement fraud.

The external auditor is a supervisory mechanism by conducting audits of financial statements to control management behavior. S.A. No. 316 shows a tense relationship between management and the current/predecessor auditors to indicate fraudulent financial reporting. Several studies suggest that audit failure increases when there is a change of auditors in the company [19] because the new independent auditors still do not know the company's condition. Besides, the limited audit process period becomes an obstacle in the audit process [20]. A study [21,22] shows that clients can use the auditor switching mechanism to reduce the possibility of observe fraud in the company's financial statements.

Arrogance is an attitude of superiority or greed from people who believe that internal control does not apply personally [23]. Study [21] explained that many images of the Chief Executive Officer (C.E.O.) displayed in the company's annual report could represent the level of arrogance or superiority of the C.E.O. The high losses due to fraudulent financial statements that have occurred in recent years have encouraged companies further to improve corporate governance. One of the ways is by creating a whistleblowing system that is used to prevent fraud. The more warnings are sent through the whistleblowing system, the smaller the risk of company losses due to the obligation to pay fines and loss of assets due to financial statement fraud. A study $[4,16]$ revealed that the use of a whistleblowing system could be used for the early detection of potential fraudulent financial statements. The existence of an independent audit committee, as an external party to the company that independently supervises the Agent, is projected to weaken senior managers' intrinsic motivation and their attention on internal earnings, which could lead to financial malfeasance [18]. The audit committee functions to reduce the risk of fraudulent financial statements $[24,25,26]$.

To understand the financial statements and the information they provide for third parties there are many techniques, models and analyses that can help usdistinguish the financial ratios. Financial ratios are a way of analyzing financial statements to assess the 
company's financial performance to obtain an overview of the company's financial position $[24,27,28]$. The financial ratios used for financial statement analysis are ratios, liquidity, solvency, and Profitability [15,27]. Liquidity measures the company's ability to pay the debt. Solvency is the ratio used to see the extent to which the company uses funding through debt; solvency is measured by the debt ratio used to see how much assets are financed by debt [29]. Profitability is a metric that measures a company's capacity to make money[30].

Organizational culture is a set of values, norms, habits, and beliefs used to guide administrative activities. An honest and ethical corporate culture can prevent financial statement fraud in companies [31]. Organizational culture will also build ethical behavior, which will influence management to implement good corporate governance so that the primary orientation is to maximize shareholder profits $[8,30]$. Organizational culture reflects character of the organization that becomes a guideline for all members in carrying out their duties to create integrity [8,32].

\section{Material and Methods}

The causal-comparative research design tests the relationship between variables and test hypotheses [33]. The population of this study is the financial sector companies listed on the Indonesian stock market for the period 2018-2020. The number of financial companies that went public listed on the Indonesia Stock Exchange from 2018 to 2020 amounted to 90 companies, so there were 270 research company analysis units. This study uses the variables of Fraudulent financial statements, financial ratios, G.C.G. mechanisms, and organizational culture. The financial statement fraud detection variable in this study was measured using the Dechow F-score model; this method was developed by Dechow in 2011 and is considered better than the Beneish M-score model used by previous researchers. This method has better accuracy and is more suitable for developing countries [11,34]. The following formula calculates the Dechow F-score method:

Table 1. Dechow F-Score Formula:

\begin{tabular}{|c|c|c|}
\hline 1 & F-score & \\
\hline 2 & Probability & $\left.1+\mathrm{e}^{\text {predicted value }}\right)$ \\
\hline 3 & Predicted Value $=$ & \\
\hline 4 & \multicolumn{2}{|c|}{ 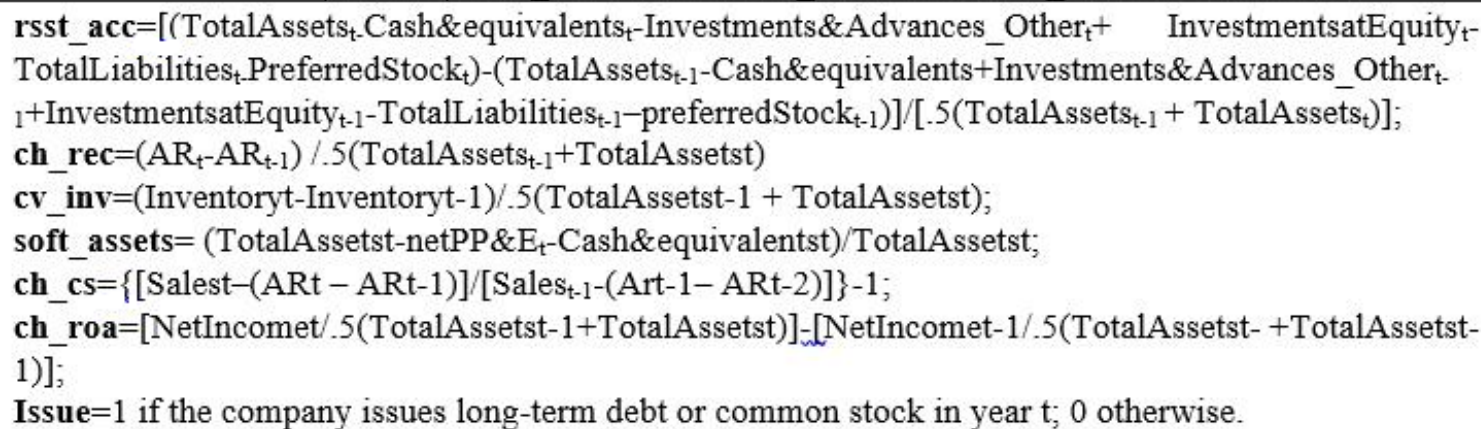 } \\
\hline
\end{tabular}

Source: Dechow, et al (2011) 
The results of the calculation "F-score can be identified as four, F-score $>2.45$ very extreme risk, F-score $>1.85$ extreme risk, F-score $>=1$ risk above normal level, and F-score $<1$ normal risk or below [35].

The measurement of the independent variables of this study is as follows:

Table 2. Operationalization variables

\begin{tabular}{|c|c|c|}
\hline Variable & Variable Measurement & Source \\
\hline $\begin{array}{l}\text { Managerial } \\
\text { Ownership } \\
\end{array}$ & $\begin{array}{c}\text { stock manager/ shares } \\
\text { outstanding }\end{array}$ & $\begin{array}{c}\text { Skousen et al. } \\
(2009)\end{array}$ \\
\hline $\begin{array}{l}\text { Auditor } \\
\text { Switching }\end{array}$ & $\begin{array}{l}\text { Code } 1 \text {, auditor switching } \\
\text { occurs, and } 0 \text { does not }\end{array}$ & $\begin{array}{c}\text { Wolfe \& } \\
\text { Hermanson } \\
(2004)\end{array}$ \\
\hline Arrogance & $\begin{array}{c}\text { Number of C.E.O. images in } \\
\text { the annual report }\end{array}$ & Crowe (2012) \\
\hline $\begin{array}{l}\text { Whistleblowing } \\
\text { System }\end{array}$ & $\begin{array}{l}\text { Number of reported fraud } \\
\text { reports in the annual report }\end{array}$ & \\
\hline Audit Committee & $\begin{array}{c}\text { Number of audit } \\
\text { committees/Number of } \\
\text { commissioners }\end{array}$ & $\begin{array}{l}\text { Skousen et al. } \\
\text { (2009) }\end{array}$ \\
\hline Liquidity & $\begin{array}{c}\text { Current assets-current } \\
\text { inventories/debts }\end{array}$ & \multirow{3}{*}{$\begin{array}{l}\text { Kasmir } \\
(2010)\end{array}$} \\
\hline Solvency & $\begin{array}{c}\text { Total assets-total } \\
\text { assets-1/total assets }\end{array}$ & \\
\hline Profitability & $\begin{array}{c}\text { Net profit/ Average of total } \\
\text { assets }\end{array}$ & \\
\hline $\begin{array}{l}\text { Organizational } \\
\text { culture }\end{array}$ & $\begin{array}{l}\text { Number of transactions with } \\
\text { related parties }\end{array}$ & $\begin{array}{l}\text { Cousins } \\
(2019)\end{array}$ \\
\hline
\end{tabular}

Data analysis used Moderated Regression Analysis (M.R.A.) method for predicting the variation of the variable by regressing more than one independent variable to the dependent variable simultaneously. M.R.A. was chosen because it can reduce estimation bias and multicollinearity, control individual heterogeneity and identify time-varying relationships between dependent and independent variables [26]. The analysis uses S.P.S.S. 24. The research model in this study is:

$$
\begin{gathered}
\mathrm{Y}_{1}: \alpha+\beta_{1} \mathrm{MO}+\beta_{2} \mathrm{AS}+\beta_{3} \mathrm{AR}+\beta_{4} \mathrm{WS}+\beta_{5} \mathrm{AC}+\beta_{6} \\
\mathrm{Liq}+\beta_{7} \mathrm{Sol}+\beta_{8} \text { Pro }+\mathrm{e} \\
\mathrm{Y}_{2}: \alpha+\beta_{1} \mathrm{MO}+\beta_{2} \mathrm{AS}+\beta_{3} \mathrm{AR}+\beta_{4} \mathrm{WS}+\beta_{5} \mathrm{AC}+\beta_{6} \\
\mathrm{Liq}+\beta_{7} \mathrm{Sol}+\beta_{8} \text { Pro }+\beta_{9} \mathrm{Y} \mathrm{OC}+\varepsilon \\
\mathrm{Y}_{3}: \alpha+\beta_{1} \mathrm{Y}_{2}+\beta_{2} \mathrm{BO}+\beta_{3} \mathrm{Y}_{2} * \mathrm{OC}+\varepsilon
\end{gathered}
$$

\section{Research Findings}

This research was conducted on financial companies listed on the Indonesian stock exchange with 90 companies listed for three consecutive years, which met the criteria for a sample of 76 companies and 228 observations.

Table 3 shows the mean fraud of 0.7510 ; this value indicates that the financial sector companies have average fraud risk or have a slight chance because the F-score value is $<1$ risk. Managerial ownership has a mean of 0.7441 , which is lower than the standard deviation, indicating that management who owns company shares has little presentation or high data variation. Auditor switching has a standard deviation value higher than the average; this shows that the company did not change auditors on average in the year of observation, so the risk of fraud is negligible. Arrogance has a mean of 7.2993, higher than the standard deviation of 4.8240 , which explains the low superiority because the C.E.O. doesn't show photos in the annual report.

Table 3. Descriptive Statistics

\begin{tabular}{|c|c|c|c|c|}
\hline & Minimum & Maximum & Mean & Std. Deviation \\
\hline Fraudulent & -0.0502 & 1.1400 & 0.7510 & 0.3010 \\
\hline Managerial Ownership & 0.0197 & 0.1830 & 0.7441 & 0.9740 \\
\hline Auditor Switching & 0.0031 & 0.2150 & 0.1251 & 4.8240 \\
\hline Arrogance & 0.0018 & 19.2210 & 7.2993 & 0.6801 \\
\hline Whistleblowing System & 0.0010 & 0.1220 & 0.7210 & 0.1600 \\
\hline Audit Committee & $-0,0330$ & 0.0480 & 0.0198 & 0.1802 \\
\hline Liquidity & -0.0768 & 0.8073 & 0.3708 & 0.1350 \\
\hline Solvency & -3.9116 & 1.8426 & 0.1085 & 0.0512 \\
\hline Profitability & 0.3130 & 0.2128 & 0.0473 & 0.0140 \\
\hline Organizational culture & 0.0110 & 0.0980 & 0.0730 & \\
\hline
\end{tabular}

Source: Secondary data processing, 2021 
The whistleblowing system has a mean of 0.7210 , more significant than a standard deviation of 0.6801. It is indicated that reporting fraud through the whistleblowing system was high in the year of observation. The audit committee has a mean of 0.0198 which is lower than the standard deviation of 0.1600 , indicating that the percentage of the audit committee has not worked well because of the small number of personnel. The financial ratios of liquidity, solvency, and Profitability have a mean more significant than the standard deviation, so it can be concluded that the company has good prospects and can pay its debts. Organizational culture has a mean of 0.0730 , which is greater than the standard deviation of 0.0140 , explaining that the company had built a good corporate culture to minimize fraud.

Table 5 describes the results of the regression test with multiple regression analyses of fraud risk. Managerial ownership has a beta coefficient of -0.0132 and has a significance of 0.0020 , indicating that management owning company shares will reduce the potential risk of fraud. Managers who own company shares can solve agency conflicts using the convergence of interest between managers and shareholders. Fraud occurs because of weak supervision to provide an opportunity for managers to behave defiantly by committing fraud; this can be anticipated if management owns company shares. According to [17,36], shares ownership by company management can equalize the interests of shareholders, improve management performance, and avoid moral hazards and adverse selection. A study [18,37] revealed that managerial ownership could reduce the potential for financial statement fraud.
Auditor switching has a beta value of 0.8470 and has a significance of 0.0153 , indicating that audit switching has a positive effect on the risk of financial statement fraud. Companies that perform audit changes in a short time create a high potential for fraud. In 2018-2020, several financial sector companies changed auditors; this indicates that the company closed deviant actions by management so that they were not audited. New auditors need a lot of time to study the company's characteristics in the audit process, so they are not able to know in detail the potential for fraud of the company. The research of [21] revealed that audit failure increased due to the change of auditors in the company. Study $[18,20,37,38]$ shows that clients can use the auditor switching mechanism to reduce the prospect of detecting fraudulent acts in the company's financial reporting. Auditor switching is the leading indicator of companies committing fraud that will harm stakeholders in the long term.

Arrogance has a beta coefficient of 0.0079 and a significance value of 0.5420 , indicating that arrogance does not affect financial statement fraud. Arrogance is an attitude of primacy or greed from people who believe that internal control does not apply personally [39]. According to $[21,23]$, the number of images of the Chief Executive Officer (C.E.O.) displayed in the company's annual finance report can represent the level of arrogance or primacy of the C.E.O. In the year of observation, the average financial sector company did not display a photo of the C.E.O. in the annual report; the company only showed a picture of the board of commissioners and president directors. So, it can be concluded that financial sector companies do not have superior arrogance or character that will trigger financial statement fraud.

Table 4. Hypothesis Test

\begin{tabular}{|c|c|c|c|c|c|c|}
\hline \multirow{2}{*}{ Variable } & \multicolumn{2}{|c|}{ Model 1} & \multicolumn{2}{|c|}{ Model 2} & \multicolumn{2}{|c|}{ Model 3} \\
\hline & $\beta$ Coef & Sig & $\beta$ Coef & Sig & $\beta$ Coef & Sig \\
\hline Managerial Ownership & -0.0132 & $0.0020^{*}$ & -0.0971 & 0.0530 & -0.6620 & $0.0020^{*}$ \\
\hline Auditor Switching & 0.8470 & $0.0153^{*}$ & 0.5864 & $0.0121^{*}$ & 0.1441 & $0.0140^{*}$ \\
\hline Arrogance & 0.0079 & 0.5420 & 0.8510 & 0.8299 & 0.4983 & $0.0219 *$ \\
\hline Whistleblowing System & -0.0615 & $0.0132 *$ & -0.6310 & 0.1210 & -0.3317 & $0.0401^{*}$ \\
\hline Audit Committee & $-0,0938$ & $0.0280 *$ & -0.2922 & 0.0507 & -0.0175 & $0.0110^{*}$ \\
\hline Liquidity & -0.8820 & $0.0330 *$ & 0.5070 & $0.0309 *$ & -0.4351 & $0.0140^{*}$ \\
\hline Solvency & 0.3918 & $0.0057^{*}$ & 0.0629 & $0.0229 *$ & 0.1507 & $0.0310^{*}$ \\
\hline Profitability & -1.1550 & $0.0410 *$ & 0.2174 & $0.0480^{*}$ & -3.0473 & $0.0490^{*}$ \\
\hline Organizational culture & & & -0.0223 & $0.0173^{*}$ & & \\
\hline R-Square & 0,3100 & & 0,0341 & & 0,5710 & \\
\hline
\end{tabular}

Source: Secondary data processing, 2021 
The whistleblowing system has a beta coefficient of -0.0615 . It has a significance value of 0.0132 , stating that the whistleblowing system harms the risk of fraud in its financial statements. A whistleblowing system is used to report fraud committed by management; this shows that the system built by the company can reduce the risk of fraud. A whistleblowing system is the early detection of fraud that has not been detected directly by the company. Early detection through the whistleblowing system mechanism will prevent the company from losses $[4,10,16,36]$.

The audit committee has a beta coefficient of -0.0938 and a significance of 0.0280 , implying that the audit committee is a risk factor in financial statement fraud. The Audit Committee has a vital and strategic role in maintaining the confidence of preparing financial statements and preserving them. The creation of an adequate corporate supervision system, as well as the implementation of Good Corporate Governance, according to $[25,26,40]$ revealed that companies that have an independent audit committee would report earnings with a smaller discretionary accrual content compared to companies. They do not have an audit committee because the audit committee has a role in overseeing the operations of a larger company to avoid fraud.

Liquidity has a beta coefficient of -0.8820 and a significance value of 0.0330 , which is accepted when liquidity hurts financial statement fraud. The liquidity ratio analyzes a company's capacity to meet its financial obligations; the more significant ratio indicates that the company has an excellent ability to pay its debts, thus avoiding fraud $[7,9]$. The low level of liquidity encourages managers to commit financial statement fraud because they feel pressured, so they will do various ways to make it look as if the company seems good by manipulating it $[6,22,26]$. According to $[23,44]$, companies with liquidity problems have a significantly greater error rate in their financial statements than companies that do not face liquidity problems.

Solvency has a beta coefficient of 0.3918 and a significance of 0.0057 , indicating that solvency positively affects financial statement fraud. Solvency measures the company's ability to pay debts with assets owned. The greater solvency of the company is an indicator that the company is not experiencing financial distress. This study finds that the solvency of financial sector companies increases the risk of financial statement fraud because, in the year of observation, many companies are having financial distress. Profitability has a beta coefficient of -1.1550 and a significance value of 0.0410 , indicating that Profitability hurts the risk of financial statement fraud. Profitability measures the management's ability and efficiency in the use of company assets to generate net income. The larger ratio means that the company's condition is getting better $[14,44]$. This ratio has a negative relationship with the possibility of fraudulent financial statements of a company. The smaller this ratio, the more likely the company is predicted to commit financial statement fraud [20,37,41].

Organizational culture has a beta coefficient of -0.0223 and a significance of 0.0173 , indicating that corporate culture hurts the risk of financial statement fraud. Organizational culture can weaken the risk of fraud in financial statements through the relationship between variables; this indicates that organizational culture has a vital role in minimizing the risk of fraud by increasing the responsibility and sense of belonging to the company by management. Thus, management is concerned about actions that will harm the company $[8,19]$. According to $[30,42,43]$ revealing culture is the best way to prevent fraud. An organizational culture that is firmly implanted will support the achievement of work performance. A culture internalized within management will influence its behavior so that the main goal is to create stakeholder satisfaction.

\section{Conclusions}

Based on the findings of the analysis, it can be concluded that the risk of financial statement fraud can be minimized. The company implements good corporate governance by giving the proportion of shares to management as a form of a convergence of interest. Auditor switching that occurs quickly is an early indication of a company committing fraudulent financial statements. The whistleblowing system and audit committee function as internal controls to detect potential fraud early and control management behavior. Financial ratios can be used to detect potential financial statement fraud; low financial ratios encourage management to commit financial statement fraud so that the company looks good. Also, the organizational culture that is internalized to management can control management behavior in acting. Based on the results of this work, financial sector companies can improve the effectiveness of corporate governance by increasing managerial ownership, changing auditors regularly and according to regulations, continuing to increase the role of the Whistleblowing system and audit committee. In addition, financial ratios can also be used as an alternative for the early detection of fraud by management.

\section{Acknowledgments}

This article is the result of research financed by the L.P.P.M. Universitas Muhammadiyah Semarang. 


\section{REFERENCES}

[1] Albrecht, W.S., Albrecht, C.O., Albrecht, C.C., \& Zimbelman, M. "Fraud Examination (Fourth Edi)". https://www.google.co.id/books/edition/Fraud_Examinatio n/R6q5BwAAQBAJ?hl=en\&gbpv=1\&dq=Fraud+Examina tion\&printsec $=$ frontcover. (accessed July. 10, 2021)

[2] ACFE. "Survey Fraud in Indonesia". ACFE Indonesia Chapter.

https://acfe-indonesia.or.id/survei-fraud-indonesia/.(access ed July. 10, 2013)

[3] AICPA. "Consideration of Fraud in a Financial Statement Audit:(supersedes Statement on Auditing Standards No. 82, AICPA, Professional Standards, Vol. 1, AU Sec. 316; and Amends SAS No. 1, Codification of Auditing Standards and Procedures, AICPA, Professional”. American Institute of Certified Public Accountants. 2002

[4] Pamungkas, I. G. T. A. "The Effects of The Whistleblowing System on Financial Statement Fraud Ethical Behavior as The Mediators”. International Journal of Civil Enginering and Technology, vol.10, no.2, pp.100-110, 2018.

[5] Ikbal, M., Irwansyah, I., Paminto, A., Ulfah, Y., \& Darma, D. C.. "Explores the Specific Context of Financial Statement Fraud Based on Empirical from Indonesia Related papers Explores the Specific Context of Financial Statement Fraud Based on Empirical from Indonesia". Universal Journal of Accounting and Finance, vol.8, no.2, pp.29-40, 2020. https://doi.org/10.13189/ujaf.2020.080201

[6] Irwandi, S. A., Hayam, U., Perbanas, W., Ghozali, I., Diponegoro, U., Faisal, F., Diponegoro, U., Pamungkas, I. D., Dian, U., \& Semarang, N. "Detection Fraudulent Financial Statement: Beneish M-Score Detection Fraudulent Financial Statement : Beneish M-Score Model”, Wseas Transactions on Business and Economics, vol.10, no.1, pp.28-35, 2019.

[7] Omukaga, K. O, "Is the fraud diamond perspective valid in Kenya?”, Emerald Insight, vol.15, no.2, pp.1-31, 2017. https://doi.org/10.1108/JFC-11-2019-0141

[8] Utami, W., Nugroho, L., Yelvionita, V., Buana, U. M., \& Barat, J, "Asian Economic and Financial Review Early Warning Industries Fraud Determinants in Kenya”, Asian Economic and Financial Review, vol.10, no.6, pp.604-627, 2019.

https://doi.org/10.18488/journal.aefr.2020.106.604.627

[9] Zhang, J., Yao, J., Wang, L., Chen, Y., \& Pan, Y, “A Financial Fraud Detection Model Based on Organizational Impression Management Strategy A Financial Fraud Detection Model Based on Organizational Impression Management Strategy", Journal of Physics: Conference Series PAPER, 2020, pp.1-12.

https://doi.org/10.1088/1742-6596/1616/1/012093

[10] Ghozali, I., \& Achmad, T, "Determinants of Fraudulent Financial Reporting and Whistleblowing System : Applying Theory of Planned Behavior", Wseas Transactions on Business and Economics, vol.16, no 3, pp.393-402, 2019.

[11] Yustia, M., Triyadi, \& Ramadhan, D, "Fraudulent Financial Statement”, Asia Pacific Fraud Journal, vol.6, no. 3, pp.159-170, 2021. https://doi.org/10.21532/apfjournal.v6i 1.202
[12] Ainul, W., Wan, A., Razali, M., \& Arshad, R, "Disclosure of corporate governance structure and the likelihood of fraudulent financial reporting”. Procedia - Social and Behavioral Sciences, vol.145, no.5, pp.243-253, 2014. https://doi.org/10.1016/j.sbspro.2014.06.032

[13] Vousinas, G, “Advancing theory of fraud: The S.C.O.R.E. Model”, Journal of Financial Crime, Emerald Insight, pp.1-25, 2011.

[14] Jatmiko, B., \& Setiawan, M. B “The Effect of External Pressure, Management Commitment and Accessibility towards Transparency of Financial Reporting”, Journal of Accounting and Investment, vol.21, no.1, pp.211-221, 2020. https://doi.org/10.18196/jai.2101140

[15] Becht, M., Bolton, P., \& Röell, A “Corporate governance and control". In Handbook of the Economics of Finance, Elsevier, vol. 1, no.21, pp. 1-109, 2003.

[16] Uwuigbe, O. R., Olorunshe, O., Uwuigbe, U., Ozordi, E., Asiriuwa, O., Asaolu, T., \& O Erin, "Corporate Governance and Financial Statement Fraud among Listed Firms in Nigeria Corporate Governance and Financial Statement Fraud among Listed Firms in Nigeria”, International Conference on Energy and Sustainable Environment, 2019, pp.1-15. https://doi.org/10.1088/17551315/331/1/012055

[17] Rochmawati, N. E., \& Musyarofah, S, "The Implementation of Good Corporate”. Jurnal Reviu Akuntansi Dan Keuangan, vol.10, no.1, pp.136-149, 2020. https://doi.org/10.22219/jrak.v10i1.10268

[18] Shi, W., Aguilera, R., \& Wang, K. (2020). State ownership and securities fraud: A political governance perspective, Wiley, pp.157-176. https://doi.org/10.1111/corg.12313

[19] Kaminski, K. A., Wetzel, T. S., Guan, L., \& Kaminski, K. A, "Can financial ratios detect fraudulent financial reporting?", Managerial Auditing Journal. Vol.19, no.1, pp. 25-58, 2008. https://doi.org/10.1108/02686900410509802

[20] Widharma, F., \& Susilowati, E, "Statement Fraud Practices with Audit Report Lag” Journal of Accounting and Strategic Finance, vol.3, no.2, pp.243-25, 2020.

[21] Hamal, S., \& Senvar, O, “Comparing performances and effectiveness of machine learning classifiers in detecting financial accounting fraud for Turkish SMEs”. International Journal Of Computational Intelligence Systems, vol.14, no.1, pp.769-782, 2021.

[22] Lunenburg, F. C, “Compliance Theory and Organizational Effectiveness", International Journal of Scholary Academic Intelectua; Diversity, vol.14, no.1, pp 23-31, 2012.

[23] Nirmala, P., Devi, C., Agung, A., Putu, G., Ayu, I. G., Budiasih, N., \& Rasmini, N. K, "The Effect of Fraud Pentagon Theory on Financial Statements: Empirical Evidence from Indonesia”, Journal of Asian Finance, Economics and Business, vol.8, no.3, pp.1163-1169, 2021. https://doi.org/10.13106/jafeb.2021.vol8.no3.1163

[24] Grove, H., \& Clouse, M, "The Impact of Corporate Governance on Fraudulent Financial Statement”, Journal of Forensic and Investigative Accounting, vol.12, no.3, pp.422-441, 2020.

[25] Indriasih, D, "The Effect of Government Apparatus 
Competence and the Effectiveness of Government Internal Control Toward the Quality of Financial Reporting in Local Government”, Research Journal of Finance and Accounting, vol.5, no.20, pp.38-47, 2014.

[26] Lastanti, H. S, "Role of Audit Committee in The Fraud Pentagon", International Journal of Contemporary Accounting, vol.2, no.1, pp.85-102, 2020.

[27] Brigham, E. F., \& Houston, J. F, “Fundamentals of financial management”, Cengage Learning, 2006, pp.1-568.

[28] Ibrani, E. Y., Faisal, F., Handayani, Y. D., \& Ntim, C. G, "Determinant of non-GAAP earnings management practices and its impact on firm value Determinant of non-GAAP earnings management practices and its impact on firm value”, Cogent Business \& Management, vol.6, no.1, pp. 40-48, 2019. https://doi.org/10.1080/23311975.2 019.1666642

[29] Cressey. D.R, “Other People’s Money”, Patterson Smith, 1953, pp. 1-800.

[30] Ferina, Mulyani, Sri. Poulus, S, “The Zero Fraud Implementation Through the Innovation”, Journal of Southwest Jiaotong University, vol.56, no.1, pp.324-334, 2021.

[31] Arens, A. A., Elder, R. J., \& Mark, B, "Auditing and assurance services: an integrated approach", Boston: Prentice Hall, 2012, pp. 1-670.

[32] Suharto, “The Effect of Organizational Culture, Leadership Style, Whistleblowing Systems, And Know Your Employee on Fraud Prevention In Sharia Banking”, Asia Pacific Fraud Journal, vol.5, no.1, pp.108-117, 2020. https://doi.org/10.2 1532/apfjournal.v5i1.141

[33] Lennel, W \& Boissoneu, R, "Using Causal-Comparative and Correlational Designs in Conducting Market Research", Journal of Professional Services Marketing, vol, 13, no.2, pp.59-80, 2008. https://doi.org/10.1300/J090v13n02_05

[34] Dechow, P. ., Larson, G. ., \& Sloan, R, "Predicting Material Accounting Misstatements”, Contemporary Accounting Research, vol. 28, no.1, pp.17-82, 2011. https://doi.org/10. 1111/j.1911-3846.2010.01041.X

[35] Thi, H., Ha, V., \& Binh, D. T, “Application of F-Score in Predicting Fraud, Errors: Experimental Research in Vietnam”. International Journal of Accounting and Financial Reporting, vol.7, no.2, pp.303-322, 2017. https://doi.org/10.5296/ijafr.v7i2.12174
[36] Sujiati, S., Ma'arif, M. S., \& Najib, M, “The Effect of Motivation and Competence on Employee Performance in Satellite Technology Center - National Institute Aeronautics and Space”, Jurnal Aplikasi Manajemen, vol.15, no.2, pp.229-237, 2017. https://doi.org/10.21776/u b.jam.2017.015.02.06

[37] Rahman, M. J., \& Yixuan Ying. (2020). The Effects of Corporate Governance and Managerial Compensation on Financial Fraud: Evidence from China”, Business and the Public Interest, vo. 20, no.3, pp.280-296, 2020.

[38] Ariyanto, D., Gilang, I. M., Made, N., Ratnadi, D., Ayu, I. G., \& Asri, M, "Detecting fraudulent financial statements in pharmaceutical companies: Fraud pentagon theory perspective”, Growing Science, vol.7, no.4, pp.1611-1620, 2021. https://doi.org/10.5267/j.ac.2021.5.009

[39] Hair, J. F., Sarstedt, M., Hopkins, L., \& Kuppelwieser, V. G, "Partial least squares structural equation modeling (PLS-SEM): An emerging tool in business research” European Business Review, vol.26, no.2, pp.106-121, 2014. https://doi.org/10.1108/EBR-10-2013-0128

[40] Mardessi, S. M., \& Fourati, Y. M, "The Impact of Audit Committee on Real Earnings Management : Evidence from Netherlands" Corporate Governance and Sustainability Review, vol.4, no.1, pp.33-46, 2020.

[41] Kristiian, N, "Behavioral Strategy Analysis Using the Fraud Diamond Theory Approach To Detecting Corporate Fraud in Indonesia Behavioral Strategy Analysis Using the Fraud Diamond Theory Approach To Detecting Corporate Fraud in Indonesia”, International Journal of Business and Management Invention, vol.9, no.4, pp.66-74, 2020.

[42] Prajanto, A., \& Pratiwi, D. R, “The Impact of Corporate Culture and financial retios on the fraudulent Financial Statement” Jurnal Dinamika Akuntansi, vol.8, no.1, pp.3952, 2016.

[43] Yelvionita, V., Utami, W., \& Mappanyuki, R, “The Effect of Internal Control and Organizational Culture on Early Warning Fraud Case Type” International Conference on Rural Development and Entrepreneurship, vol.5, no.1, pp.1401-1438, 2019.

[44] Mehmet Nar ,"The Relationship between Credit Default Swaps and Net Portfolio Investments: The Case of Turkey," Universal Journal of Accounting and Finance, Vol. 9, No. 2, pp. 252 - 261, 2021. DOI: https://doi.org/10.13189/ujaf.20 21.090215 